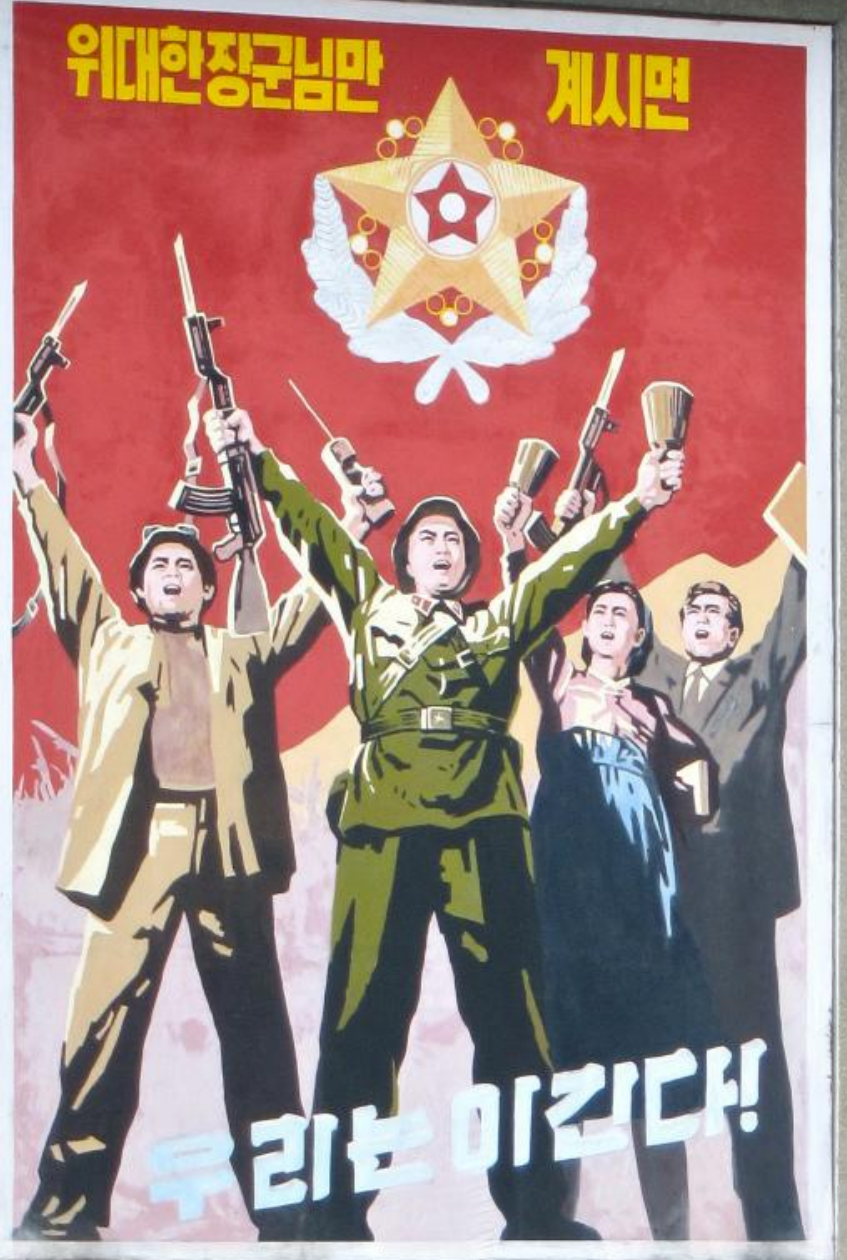

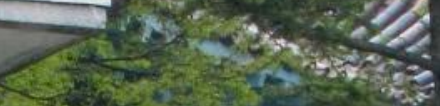
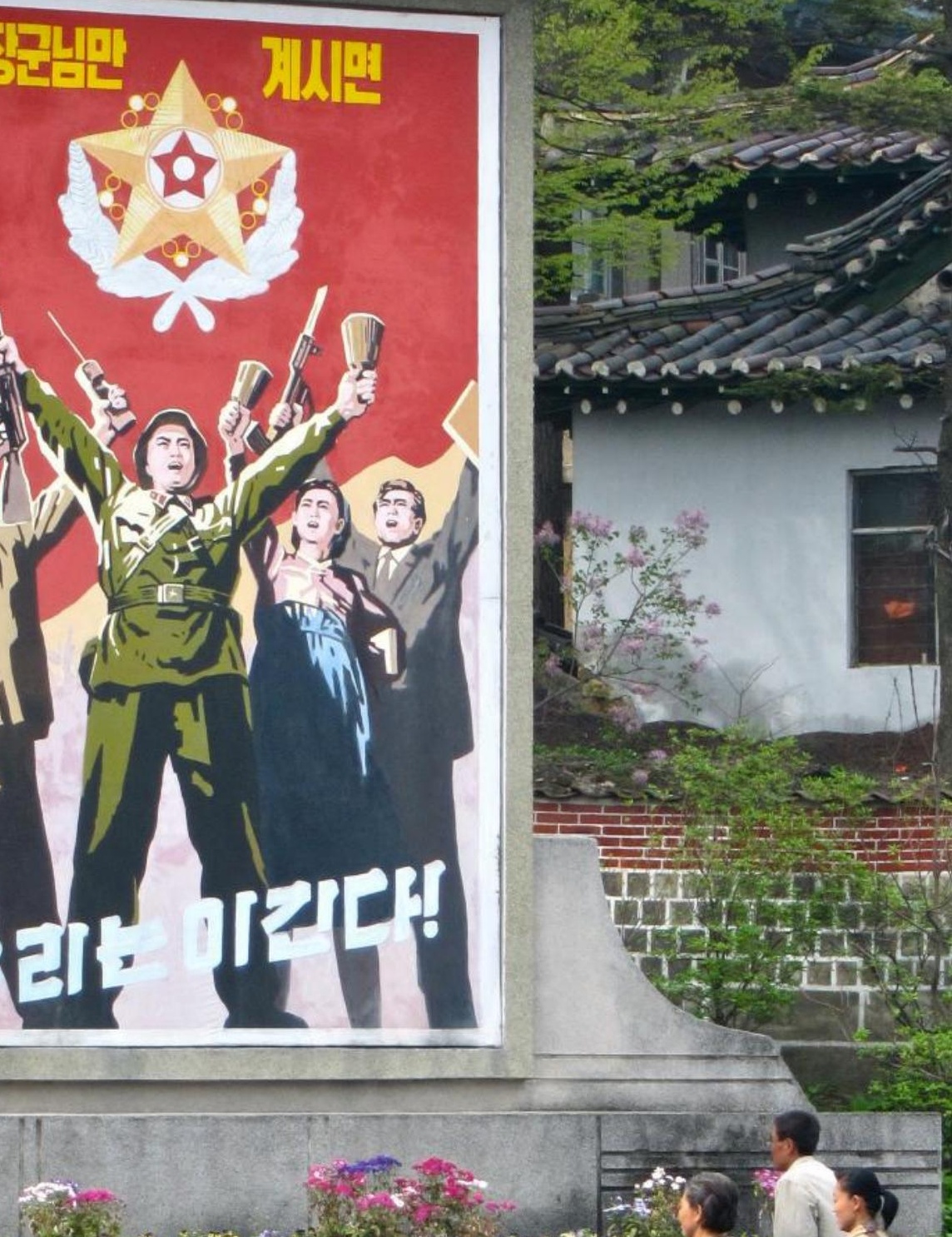

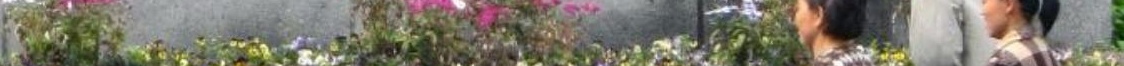

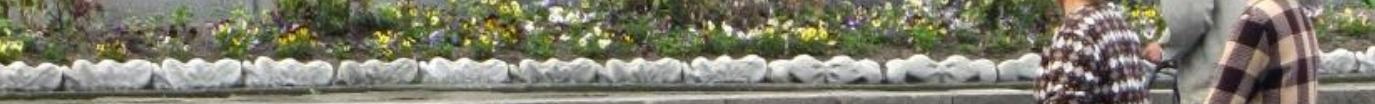

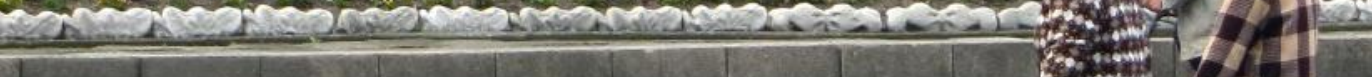

Photo by John Pavelka on Flickr, used under CC by 2.0 license




\section{THE SOLDIERS OF SONGBUN: MILITARIZATION, HUMAN RIGHTS ABUSE AND CHILDHOOD EXPERIENCES OF NORTH KOREAN YOUTH}

\section{By Peter Steele}

Master's candidate in

International Development

Studies at Dalhousie University

\section{ABSTRACT}

North Korea is an enigma. The United Nations (UN) states that it is "... without parallel in the contemporary world ..." in terms of abuse, exploitation and lack of civil rights. ${ }^{1}$ No other rogue state commands the attention and mystique as the isolated nation of the Democratic People's Republic of Korea (DPRK). Despite an increasingly prevalent international front, including warming relations with South Korea ${ }^{2,3}$ and the threat of nuclear weapons $s^{4}$, everyday citizens

$1 \quad$ Human Rights Watch, "UN: North Korea Exploiting Children", Geneva: Human Rights Watch, Feb. 8, 2017: para. 9. Retrieved from https://www.hrw.org/news/2017/02/08/un-north-korea-exploiting-children.

2 Al Jazeera, “North Korea 'seeks closer South Korea ties, reunification'”, Al Jazeera, Mar. 6, 2018, Retrieved from https://www.aljazeera.com/news/2018/03/north-korea-seeks-closer-south-korea-tiesreunification-180306062814201.html.

3 Y. Seo \& L. Smith-Spark, "North, South Korea to hold reunions for families long separated by war", CNN Asia, Jun 22, 2018, Retrieved from https://www.cnn.com/2018/06/22/asia/koreas-family-reunions-intl/index.html.

4 E. Stewart, "North Korea is reportedly making more nuclear weapon fuel", Vox, Jun 30, 2018. 
remain hidden. Public displays of Olympic cheerleaders ${ }^{5}$ or the admittance of "K-Pop" stars across the Korean Demilitarization Zone (DMZ) ${ }^{6}$ distract from the widespread human rights abuses and public indoctrination that is second nature in the country. ${ }^{7}$ But this is no surprise; In the DPRK, the leader is above all else. While marginalized groups in other countries may be granted a voice by international organizations, the vulnerable in North Korea are obscured in the shadow of the great leader's actions.

The life of children in North Korea can take many different forms, but all share a legacy of systematic abuse and manipulation which infringe on the rights of the child. ${ }^{8}$ Despite widespread condemnation, the DPRK remains steadfast in its policies of lifelong militarization and marginalization. ${ }^{9}$ The lives of this underrepresented population are caught between the innocence of childhood and the complexities of daily life in North Korean society, leaving many children to experience maltreatment.

Through this article, I explore the everyday lives of the nation's children. With an explicit effort to identify the legacy of abuse and militarization of children in the nation, I analyze how the government ingrains obedience and fear into their young people. The actions of the state directly infringe the rights set out by the Convention on the Rights of the Child (CRC) $)^{10}$, which suggests that the international community must act to preserve the right to childhood just as it attempts in other countries. Despite North Korea's ratification of this agreement ${ }^{11}$, there has been no effort to improve the lives of children or to curb the government-sanctioned abuse which mires the lives of young people in the nation. With this normalization of violence, we must ask how these aspects feed into the dangerous culture of extremism and

Retrieved from https://www.vox.com/world/2018/6/30/17520638/north-korea-increased-activity-nuclear-trump.

B. Haas, "North Korea's cheerleaders amaze and appal at the Winter Olympics," The Guardian, Feb.

13, 2018. Retrieved from https://www.theguardian.com/world/2018/feb/13/north-korean-cheerleaders-winter-olympics.

6 Y. Seo, "K-pop stars to perform in North Korea in art troupe visit," CNN Asia, Mar. 20, 2018, Retrieved from https://www.cnn.com/2018/03/20/asia/korea-pop-art-troupe-north-korea-intl/index. html.

7 Human Rights Watch. Country Summary - North Korea. New York: Human Rights Watch, Jan. 2017, Retrieved from https://www.hrw.org/sites/default/files/northkorea_2.pdf.

8 United Nations General Assembly Resolution 44/25, Convention on the Rights of the Child (CRC), Nov. 1989, United Nations, pg. 1-12, Retrieved from https://www.ohchr.org/Documents/Professionallnterest/crc.pdf.

9 Human Rights Watch, "UN: North Korea Exploiting Children".

10 General Assembly Resolution, CRC, pg. 1-12.

11 Human Rights Watch, Human Rights in North Korea: June 2018 Briefing Paper, New York: Human Rights Watch, Jun. 2017, Retrieved from https://www.hrw.org/news/2018/06/05/human-rights-northkorea. 
loyalty that debilitates the lives of young people in the nation. Failure to recognize the severity of this situation will result in the continued maltreatment of North Korea's youth, in favour of militarism and fear.

\section{ON STUDYING NORTH KOREA}

Before presenting the experiences of children in North Korea, it is important to contextualize the academic study of this closed nation. Unlike other countries, there is no opportunity to undertake an independent research study. The information collected by visitors to the country is curated by the government, preventing truly objective academic research. To counter this, many authors turn to the testimonies of North Korean refugees and defectors, which share common experiences of tragic state treatment through UN depositions. ${ }^{12}$ Ultimately, these testimonies can generate bias and complex narratives that waver under the intense scrutiny of the international spotlight. ${ }^{13}$ Rather than rejecting defector testimony, researchers must deconstruct the pressure of fulfilling the expectations of eager interviewers, and the influence of the cultural norms of this group to obey authority or cling to survival. ${ }^{14}$ Through the limitations of capturing the reality of North Korea, we must instead carefully develop narratives based on common elements of the information that escapes the country. ${ }^{15}$ Ultimately, this study of North Korea relies on a mix of defector testimony, official mandates from governing bodies, publications from news outlets, traditional academic literature, and more.

\section{POLICIES OF THE NORTH KOREAN STATE}

In North Korea, the experiences of its youngest citizens vary within huge extremes, stemming from the position of families within society. To understand the DPRK, we must recognize the country's complete dedication to their social structures and leadership. With an emphasis on unwavering obedience, North Koreans celebrate the violent and oppressive institutions which formally define their society. Of note, Juche and Songun are two policies that keep people devoted to government mandates. Juche is the DPRK's institutionalized ideology of self-reliance which has been in place for over five decades. ${ }^{16}$ This strategy ties together North Korea's international isolationism with methods to develop unity and national sovereignty, thus encouraging the concentration of power among the elite. ${ }^{17}$ In alignment

12 United Nations Human Rights Council (OHCHR), Commission of Inquiry on Human Rights in the Democratic People's Republic of Korea - Public Hearing in Seoul (Unofficial Transcripts). [Multiple Resources].

15 Personal communications with Dr. Robert Huish, Office meeting, March 2018.

16 J. Suh, "Introduction: Making sense of North Korea - Institutionalizing Juche at the nexus of Self and Other," Journal of Korean Studies 12, no. 1 (2007): pg. 3-4. 
with this philosophy, Songun relays collectivist action under a "military-first" policy that requires militaristic indoctrination of all citizens regardless of age. ${ }^{18}$ These structures help to maintain songbun, which is the state-sanctioned classification strategy of social hierarchy that - intersecting with gender, disability and political discrimination - defines the permanent social standing of North Korean citizens from birth. ${ }^{19}$ The interaction of these three policies have undue influence on the lives of all children in the country, as early experiences of social categorization and militarization prepare them for acquiescence with the structures of the Workers' Party of Korea.

Ultimately, these ideological pillars define the experiences of young people in North Korea. With an unwavering constitution of support for the leader, there are no attempts within these structures to safeguard childhood experience. The familial relationships that dominate the lives of young children in much of the world are lost here. Defectors have commented that they do not even know their own parents birthdays but have elaborate celebrations dedicated to the Kim family. ${ }^{20}$ Similarly, there are testimonies of defectors in political prison camps who would willingly give up their own family members upon hearing of escape attempts, but actively shared the little food they had with military guards - who represent the authority and power of the state. ${ }^{21}$ These efforts to eliminate individuality and freedom directly defy Articles 12 through 16 of the $C R C^{22}$, through a fundamental effort to control the experiences of young people. This blatant abuse remains unchecked at the international stage and comes at the consequence of the most vulnerable. The erasure of the common experiences of children is profound, and it is necessary to recognize how these fundamental shifts, which happen so early in life, come to define youth in the nation.

\section{EDUCATION, MILITARIZATION \& THE EXPECTATIONS OF YOUTH}

The indoctrination and militarization process of North Korean children begins formally through education. At nursery schools, children sing nationalistic anthems while holding toy machine guns and watch cartoons featuring anthropomorphized representations of the military fighting others representing the Americans and Japanese. ${ }^{23}$ Children's literature is

18 J. Woo, "Songun politics and the political weakness of the military in North Korea: an institutional account," Problems of Post-Communism 63, no. 4 (2016): pg. 253-254.

19 United Nations General Assembly, Report of the commission of inquiry on human rights in the Democratic People's Republic of Korea, A/HRC/25/63 (Feb. 7, 2014): pg. 8.

20 United Nations Human Rights Council (OHCHR), Commission of Inquiry on Human Rights in the Democratic People's Republic of Korea - Public Hearing in Seoul - Afternoon Session, Aug. 20, 2013, Retrieved from http://www.ohchr.org/EN/HRBodies/HRC/ColDPRK/Pages/CommissionlnquiryonHRinDPRK.aspx.

21 Ibid.

22 General Assembly Resolution, CRC, pg. 4-5.

23 J. Makinen, "At a North Korean nursery school, tots get an early education in weaponry," Los 
filled with Soviet influence and a celebration of technology to defeat American imperialism. ${ }^{24}$ In kindergarten, five-year-olds are taught to believe that the state is heaven on earth. ${ }^{25}$ This ideological training, to control children's impressions of the state, directly violates $C R C$ articles dedicated to education and freedom of expression. ${ }^{26}$

While North Korean education maintains a familiar curriculum of language, math, and literature, the content of these classes is aligned with ideological training. ${ }^{27}$ Even within these universal subjects, all teachings prescribe to Kim Il-sung's 1977 thesis on socialist education, which emphasizes the role of politics in teaching to develop revolutionary spirit. ${ }^{28}$ For example, children in kindergarten read ideological children's books ripe with anti-American messages, while math problems in higher grades discuss military action and the killing of Japanese spies. ${ }^{29}$ For the few schools that maintain foreign language classes, students are taught to say phrases such as "long live great leader generalissimo Kim Il-sung" before simple greetings. ${ }^{30}$ These methods reflect the priority of indoctrination and support for the state within education.

Beyond these familiar classes, students are required to learn "socialist ethics" and the historical legacy of the DPRK state. ${ }^{31}$ Through these courses, children are taught to model themselves on the successes of the state, with great attention paid to memorization and understanding of Juche principals, the evil nature of "liberalism", and the notion of placing the collective before oneself. ${ }^{32}$ Efforts to encourage obedience and support are fundamental in the curriculum and result in an unrivalled effort to mainstream militarization within formal teaching.

Angeles Times, May 4, 2016: para. 10-14. Retrieved from http://www.latimes.com/world/asia/la-fgnorth-korea-nursery-school-20160504-snap-htmlstory.html.

24 D. Zur, "Let's Go to the Moon: Science fiction in the North Korean children's magazine Adong Munhak, 1956-1965," The Journal of Asian Studies 73, no. 2 (2014): pg. 327-334.

25 C. Byung-Ho, "Living Dangerously in two worlds: The risks and tactics of North Korean refugee children in China," Korea Journal 43, no. 3 (2003): pg. 192.

26 General Assembly Resolution, CRC, pg. 1-12.

27 F. Tertitskiy, "Life in North Korea - The early years," The Guaridan (UK), Dec. 21, 2015: para. 3. Retrieved from https://www.theguardian.com/world/2015/dec/21/life-in-north-korea-the-early-years.

28 P. French, "A day in the life of Pyongyang - how North Korea's capital goes to work," The Guardian (UK), May 2, 2014: para. 2. Retrieved from https://www.theguardian.com/world/2014/may/02/northkorea-a-day-in-the-life-pyongyang.

29 A. Fifield, "North Korea begins brainwashing children in cult of the Kims as early as kindergarten." The Washington Post, Jan. 16, 2015: sect. 2. Retrieved from https://www.washingtonpost.com/ world/asia_pacific/for-north-koreas-kims-its-never-too-soon-to-start-brainwashing/2015/01/15/ a23871c6-9a67-11e4-86a3-1b56f64925f6_story.html.

30 Tertitskiy, "Life in North Korea," para. 3.

31 Ibid, para. 3.

32 Byung-Ho, "Living Dangerously in two worlds," pg. 192. 
As student's progress through the education system, these teachings translate into practical measures. This includes children in secondary school (between the ages of 10 and 16) participating in annual trips to perform agricultural labour, and working on local labour projects to raise funds for their school. ${ }^{33}$ During these month-long trips, students work 12 to 14 hour days. ${ }^{34}$

Despite having claimed to end child labour over 70 years ago, the state still requires students to participate in a variety of forced labour projects in paramilitary brigades, known as dolgyeokdae, which includes extended working hours and corporal punishment. ${ }^{35}$ Construction projects, including the breaking down of rocks ${ }^{36}$, which yield buildings, statues, roads and railroads ${ }^{37}$, and provide no financial or professional benefit to the students. Teenagers work on construction projects through the day and night with little safety equipment, all with the purpose of demonstrating loyalty to the supreme leader. ${ }^{38}$ Earning less than $\$ 1$ a day ${ }^{39}$, this is simply a further methodology to suppress and indoctrinate youth with collectivist notions of support for the Kim regime. ${ }^{40}$ Protection from economic exploitation, access to leisure and low standards of living are also guaranteed within the $C R C^{41}$, and the DPRK has fundamentally failed these principles.

\section{Despite having claimed to end child labour over 70 years ago, the state still requires students to participate in a variety of forced labour projects in paramilitary brigades.}

Outside the classroom, the efforts of indoctrination remain strong through extracurricular activities. Just as dolgyeokdae represents a formal avenue for schools to enforce collective labour,

33 Human Rights Watch, Country Summary, pg. 4.

34 M. Oppenheim, "What it's like to be a teenager in North Korea," The Independent (UK), Sept. 9, 2016: para. 5. Retrieved from https://www.independent.co.uk/news/people/north-korea-independence-day-dating-love-sex-drinking-video-games-and-being-gay-in-north-korea-life-a7233526.html.

35 Human Rights Watch, “UN: North Korea Exploiting Children”, para. 2.

36 R. Pinnington, "Brutal life of North Korea children: Propaganda in schools and forced to watch executions," Express (UK), Nov. 4, 2017, para. 4. Retrieved from https://www.express.co.uk/news/ world/875134/North-Korea-child-labour-abuse-Kim-Jong-un-Human-Rights-Watch.

37 Human Rights Watch, “UN: North Korea Exploiting Children”, para. 6.

38 Open North Korea, Contemporary form of Slavery, Dolgyeokdae in North Korea, (n.d.): pg. 1-2. Retrieved from http://tbinternet.ohchr.org/Treaties/CRC/Shared\%20Documents/PRK/INT_CRC_ NGO_PRK_26561_E.pdf.

39 S. Boroweic, "North Koreans perform \$975 million worth of forced labor each year," Los Angeles Times, Oct. 6, 2016: para. 6-8. Retrieved from http://www.latimes.com/world/asia/la-fg-north-koreaforced-labor-20161006-snap-story.html.

40 French, "A day in the life of Pyongyang," para. 2.

41 General Assembly Resolution, CRC, pg. 1-12. 
there are many other institutions in which North Korean children are forced to participate in. For children aged of 7 to 13, there is mandatory participation in the state-sponsored Korean Children's Union ${ }^{42}$, which furthers the opportunities for indoctrination and enforcing the collective militarization of the population. In their oath of allegiance, which occurs during the admission ceremony, they proclaim their support for the regime with the following:

\section{I join the ranks of the Korean Children's Union, founded by the Great Leader Generalissimo Kim Il-sung and shined upon by the Great Guide Commander Kim Jong-il, do hereby swear to always and everywhere think and act according to the teaching of the [Kim regime] and to become a good reservist of the brilliant cause of constriction of Communism, which is carried along from generation to generation by the great revolutionary deed of Juche. ${ }^{43}$}

This militarized proclamation, recited by thousands of North Korean children each year, demonstrates the purpose of such a children's union: providing emphasis on ideological training. When children age out of this program, they join groups such as the Socialist Youth League (for ages 14-30) ${ }^{44}$, which encourages the practices of Juche and state participation through formal education sessions. ${ }^{45}$ In both settings, youth participate in group criticizing sessions, where students attack one another's dedication to the mission of the state. ${ }^{46}$ Under the guise of a social organization, these criticizing sessions encourage students to act towards rectification and place blame on others for not participating in communist structures. ${ }^{47}$

Ultimately, these brain-washing practices influence the children of North Korea in the most fundamental of ways. There is no opportunity for any personal freedom, as North Korean children have training and education that is rooted in revolutionary ideology ${ }^{48}$ These efforts provide a specific emphasis for the state to enforce mutual distrust for other students, loyalty to the state, a fear of the outside world, experiences in labour and military organization, and a hatred of North Korea's "enemies". Through education, the regime strips away the innocence of

42 Human Rights Watch, "UN: North Korea Exploiting Children”.

43 Tertitskiy, "Life in North Korea," para. 3.

44 Human Rights Watch, "UN: North Korea Exploiting Children".

45 Oppenheim, "What it's like to be a teenager in North Korea," para. 2.

46 United Nations Human Rights Council (OHCHR), Commission of Inquiry on Human Rights in the Democratic People's Republic of Korea - Public Hearing in Seoul - Morning Session, Aug. 21, 2013, pg. 47. Retrieved from http://www.ohchr.org/EN/HRBodies/HRC/CoIDPRK/Pages/CommissionInquiryonHRinDPRK.aspx.

47 United Nations Human Rights Council (OHCHR), Commission of Inquiry on Human Rights in the Democratic People's Republic of Korea - Public Hearing in Seoul - Morning Session, Aug. 22, 2013, pg. 16. Retrieved from http://www.ohchr.org/EN/HRBodies/HRC/CoIDPRK/Pages/CommissionInquiryonHRinDPRK.aspx. 
childhood in favour of normalized violence and militarism. Even the constitution references the importance of this education, as to enforce "socialist" pedagogy and influence the next generation to fight. ${ }^{49}$ Education is a fundamental tactic of the state to assert control, which is in contravention of Articles 18 through 20 of the $C R C .^{50}$ Beyond this, the abuse that is prescribed in school settings offers irreparable damage and a fundamental betrayal of the right to childhood. The normalized violence (physical and structural) in these settings defies any suggestion of protecting young people in the country from injustice.

\section{POVERTY, SOCIAL STATUS AND ABUSE}

Outside of Pyongyang, the proficiency of education is hindered by widespread poverty. For example, in 1998 it was reported that, although a quarter of students (representing the elite) attended all classes, an additional quarter had no access to food during lunch, while the remaining half could only attend morning classes or could not attend at all. ${ }^{51}$ As songbun classifications often defines a citizen's life, the children of elites receive disproportionate access to the best schools and social programs. ${ }^{52}$ While one might assume this alleviates indoctrination for lower caste, this lack of opportunity often forces children into positions of exploitation by other means. Although dolgyeokdae is a practice which most school participate in, for children of lower classes, it represents a singular opportunity for post-secondary education, as families are unable to pay fees. ${ }^{53}$ Children of low songbun status often end up doing forced labour as part of military brigades for up to 10 years without pay, building public infrastructure to further the "socialist" mission of the DPRK. ${ }^{54}$

Children of lower status are further marginalized through the isolationist policies of the state. Children often end up independent at an early age. ${ }^{55}$ In the countryside, the early lives of children are often categorized with malnourishment and cold, as food security and power are very limited. The state assumes responsibility for early child care through the Public Distribution System (PDS), which is intended to provide foodstuffs and medical support. ${ }^{56,57}$

49 International Constitutional Law Project, North Korean Constitution, articles 43-45. Retrieved from http://www.servat.unibe.ch/icl/kn00000_html.

50 General Assembly Resolution, CRC, pg. 5-6.

51 Byung-Ho, “Living Dangerously in two worlds," pg. 193.

52 Human Rights Watch, Country Summary, pg. 2.

53 Human Rights Watch, "UN: North Korea Exploiting Children".

54 Ibid, para. 6-7.

55 Byung-Ho, "Living Dangerously in two worlds," pg. 191.

56 Ibid, pg. 193.

57 Tertitskiy, "Life in North Korea," para. 2. 
However, this dysfunctional system often fails to provide for marginalized groups. ${ }^{58}$ Documented experiences include fathers encouraging children to steal from well-off neighbours, participation in the black market, and even foraging in the mountains for sustenance. ${ }^{59}$ With widespread reports of the malnutrition of North Korea children, which includes some 37\% who are stunted during development and an additional 23\% who are underweight ${ }^{60}$, youth often suffer from skin diseases and delayed puberty due to poor nutritional diets. ${ }^{61}$ Protein deficiency, respiratory problems, and diarrhea are rampant in times of crisis. ${ }^{62,63}$

Orphans are a particularly marginalized group within North Korea. As family units are challenged by the widespread poverty in the country, leading to abandonment ${ }^{64}$ and children leaving their families to alleviate burden ${ }^{65}$, there is a large contingent of young people without support. Contrary to the togetherness of militarized practices, these children are left to fend for themselves in the street, begging for food or resorting to wild vegetation like grasses, and sleeping next to transformers to stay warm in the punishing winter. ${ }^{66}$ For children who end up in orphanages, domestic abuse and deadly disease is common. ${ }^{67}$ During the height of famine in the 1990s, children in orphanages were left without support. Defectors recount tales of subsisting on lice and corn kernels from cow feces ${ }^{68}$, while another claimed 24 of the 75 children in their orphanage had died from malnutrition. ${ }^{69}$ Homelessness among

58 J. Katona-Apta, A. Mokdad, "Malnutrition of Children in the Democratic People's Republic of North Korea," Community \& International Nutrition 128 (1998): pg. 1315-1317.

59 J. H. J. Han, "Beyond Safe Haven: A critique of Christian custody of North Korean migrant in China," Critical Asian Studies 45, no. 4 (2013): pg. 551-552.

60 R. Margesson, E. Chanlett-Avery, A. Bruno, "North Korean refugees in China and Human Rights issues: International response and US policy options." Congressional Research Service (Sept. 26, 2007): pg. 7.

61 Byung-Ho, “Living Dangerously in two worlds," pg. 203.

62 J. Katona-Apta, A. Mokdad, "Malnutrition of Children in the DPRK," pg. 1317.

63 D. Sagolji, "Damir Sagolji: North Korea [Photo Series]," Reuters, Feb. 10, 2012, Retrieved from https://www.reuters.com/news/picture/damir-sagolj-north-korea-idUSRTR2XLL4.

64 M. Park, “Orphaned and homeless: Surviving North Korea," CNN (USA), May 14, 2013, para. 1. Retrieved from https://www.cnn.com/2013/05/13/world/asia/north-korea-orphans/.

65 Byung-Ho, "Living Dangerously in two worlds," pg. 200.

66 Park, "Orphaned and homeless: Surviving North Korea," para. 1-2.

67 E. Shim, "North Korea defector: Children ate lice to stay full," United Press International, Nov. 22, 2017, para. 3-4. Retrieved from https://www.upi.com/North-Korea-defector-Children-ate-lice-tostay-full/7661511370351/.

68 Ibid, para 1-2.

69 P. Walker, "North Korea: 'You are brainwashed from the time you know how to talk'," The Guardian (UK), Feb. 17, 2014: para. 11. Retrieved from https://www.theguardian.com/world/2014/feb/17/ north-korea-human-rights-abuses-stories-un-brainwashed. 
children is so widespread in North Korea that they have adopted the name Kotjebi. This term, which translates to mean "fluttering swallow"70, represents groups of 12- to 18-year old street children. ${ }^{71}$ Often concentrated near the Chinese border, these street children are motivated by money, opportunity, access to medicine, lost family members, and adventure to dart back and forth between the DPRK and China. ${ }^{72}$ Children often engage in local industry, beg, and steal to earn enough money for basic necessities that are out of each in their home nation. ${ }^{73}$ These young people face a constant threat of being caught by North Korean officials and have no legal standing to access Chinese services. ${ }^{74}$ These conflicted children feel guilt for abandoning their country, while simultaneously experiencing a vagrant and rebellious lifestyle unimaginable in the DPRK. ${ }^{75}$

For children that are caught, the inevitable destination for betraying their country is a prison camp. The children in these institutions are often sentenced in relation to a family member's crime or generational punishment, which results in children being born into camps. ${ }^{76}$ This means, regardless of age, children are subject to the human rights abuses that occur within the camps. ${ }^{77}$ Physical abuse, forced labour, menial chores and sexual abuse are documented within camp settings ${ }^{78,79}$, all of which are covered by the CRC..$^{80}$ Young guards, who are groomed for torture due to a strong ideological background ${ }^{81}$, are rewarded with higher education, denoting the militarized hierarchy within political camps. ${ }^{82}$ Although children have access to education, the tenets of Juche are less dominant in favour of lifestyles that emphasize hard labour. ${ }^{83}$ For prisoners themselves, the ideologies of Juche are taught but remain secondary to

70 S. McPhee, "Kotjebi: North Korean children in China," Asian Affairs 45, no. 3 (2014): pg. 486.

71 Byung-Ho, "Living Dangerously in two worlds," pg. 199.

72 McPhee, “Kotjebi: North Korean children in China," pg. 486.

73 Byung-Ho, “Living Dangerously in two worlds," pg. 199-200.

74 McPhee, "Kotjebi: North Korean children in China," pg. 488.

75 Byung-Ho, “Living Dangerously in two worlds," pg. 207-208.

76 Pinnington, "Brutal life of North Korea children", para. 2-3.

77 Human Rights Watch, Country Summary, pg. 3-4.

78 Pinnington, "Brutal life of North Korea children", para. 3.

79 OHCHR, Commission of Inquiry - Afternoon, Aug. 20, 2013, pg. 8-9.

80 General Assembly Resolution, CRC, pg. 1-12.

81 United Nations Human Rights Council (OHCHR), Commission of Inquiry on Human Rights in the Democratic People's Republic of Korea - Public Hearing in Seoul - Afternoon Session, Aug. 21, 2013, pg. 22, Retrieved from http://www.ohchr.org/EN/HRBodies/HRC/CoIDPRK/Pages/CommissionInquiryonHRinDPRK.aspx.

82 Ibid, pg. 3-19.

83 Ibid, pg. 8. 
survival tactics. ${ }^{84,85}$ The constant threat of being placed in these unfortunate circumstances also contributes to the militarized and collectivist actions of young civilian populations. ${ }^{86}$

Although these latter comments on the daily lives of marginalized children in North Korea are pointed towards human rights abuse, it is important to recognize how this institutionalized maltreatment helps to maintain North Korean society. Defectors who endured political camps have described apathy towards Juche as a wider principle, but the maintenance of allegiance to the leadership is harder to shake. ${ }^{87}$ Ultimately, these experiences of abuse present a terrifying reality for the DPRK's youngest citizens, and further reflect a harmful culture of State self-reliance and placing the collective first. These children are not to blame for the maintenance of this system, as the indoctrination process offers no alternative. However, it is relevant to reflect upon these experiences as part of the systematic abuse towards children that extends beyond propaganda and militarization. With countless articles of the CRC being disregarded, including those referencing child health and welfare ${ }^{88}$, there is ample opportunity for the international community to respond. As the experiences of these children are an unthinkable tragedy, the regime directly benefits from fear and control.

\section{CONCLUSION}

Even in our globalized world, North Korea is absolute in its ideological stance. Children grow up in a society that clearly defines what they will be able to say and do, and conversely defines the consequences for failing to prescribe to the unavoidable indoctrination. The experiences of children in North Korea are desperate. Whether considering young adults forced to be part of labour organizations ${ }^{89}$, or orphan children on the Chinese border left to fend for themselves ${ }^{90}$, there is no lack of tragedy within this case study. On the topic of militarization and government suppression, the lives of the DPRK's youngest citizens are dominated with explicit attempts to indoctrinate and control them. On the surface, North Korean children are not so different: they watch cartoons, they go to school, they socialize and celebrate birthdays. The difference is in the way their government forces these actions into their lives. The colourful cartoons present anti-foreigner and pro-military propaganda. ${ }^{91,92}$ Education presents an intersection

84 OHCHR, Commission of Inquiry - Afternoon, Aug. 20, 2013, pg. 33.

$85 \mathrm{OHCHR}$, Commission of Inquiry - Morning, Aug. 21, 2013, pg. 10.

86 Ibid, pg. 40.

87 Ibid, pg. 10

88 General Assembly Resolution, CRC, pg. 1-12.

89 Open North Korea, Contemporary form of Slavery, pg. 1-2.

90 McPhee, "Kotjebi: North Korean children in China," pg. 486.

91 C. Richardson, "Still quite fun to read': An introduction to North Korean children's literature," Sino-NK, Sept. 7, 2013: para. 3.

Makinen, "At a North Korean nursey school", para. 7-9. 
between access a militarized curriculum, and the inequalities of the songbun structure. ${ }^{93}$ Socializing is relegated to high-stakes criticizing sessions with the Socialist Youth League. ${ }^{94}$ The celebration of birthdays is exclusive to that of the Kim family. ${ }^{95}$

\section{On the topic of militarization and government suppression, the lives of the DPRK's youngest citizens are dominated with explicit attempts to indoctrinate and control them.}

These experiences cannot go unrecognized. Although North Korea remains isolated and unstable, the children within its borders are subject to unimaginable trauma. Discussions of reunification present a forum for change but cannot be at the expense of these young victims of such extreme political ideologies. With the acknowledgement that the Kim regime has deliberately disregarded the $C R C^{96}$, it is necessary to commit additional resources to the plight of children in North Korea. The CRC notes that it is the responsibility of other ratified countries to enforce these rights ${ }^{97}$, meaning that leaving the actions of North Korea unchecked results in the systematic failure of victims of abuse. Although some research demonstrates their situation, the isolated nature of the country often leaves formal academic investigation unsuitable. As such, groups like Human Rights Watch and the UN have provoked combative responses through inquiries and depositions, but more tangible efforts are needed. Efforts to respond to North Korea cannot be solely rooted within fear of nuclear war - not while Juche and songbun continues to exploit the innocence of children.

Thankfully, cracks have begun to show in the North Korean exterior: the restrictive practices of the state are being challenged by American and South Korean media. ${ }^{98,99}$ Although they can be publicly executed for the possession of such materials, the increasing need for freedom has galvanized young people to seek a brighter future. Kotjebi do not point to famine or desperation as justification for their illicit journey into China, but rather the want for better opportunity. ${ }^{100}$

93 Human Rights Watch, Country Summary.

94 Human Rights Watch, "UN: North Korea Exploiting Children”, para. 4.

95 French, "A day in the life of Pyongyang," para. 7.

96 General Assembly Resolution, CRC, pg. 12-15.

97 Ibid, pg. 12-13.

98 Oppenheim, "What it's like to be a teenager in North Korea," para. 3.

99 J. Jones, "A digital escape from North Korea's secret state: Kim Jong-un faces threat from undercover films posted on the web," The Independent (UK), Nov. 10, 2013. Retrieved from http:// www.independent.co.uk/news/world/asia/a-digital-escape-from-north-koreas-secret-state-kim-jongun-faces-threat-from-undercover-films-8931494.html. 
With little concept of the outside world ${ }^{101}$, it might be assumed that the unwavering obedience is absolute. However, discontent and apathy towards this ideological upbringing is inevitable with the extreme scarcities that exist within the state. ${ }^{102}$ It would be wrong to suggest that North Korean children are not subject to extreme mind training ${ }^{103}$, but it would be equally unjust to suggest that youth in the nation are irreconcilably corrupted. Childhood wonder remains within North Korea, even as the articles of the $C R C$ are betrayed by the state.

In pre-schools across the world, children play with toys and watch cartoons. North Korean children do these things as well - after all, children share many common experiences. But children should never have to experience the constant threat of war, arduous military exercise, severe malnutrition, physical and emotional abuse, and harmful ideologies. With a greater effort to understand the complexities of the North Korean situation, as well as efforts to bring human rights and glimpses of the outside world into the country, the plight of children can be addressed. Approaching its $30^{\text {th }}$ anniversary, the $C R C$ offers important requirements to maintain the dignity and rights of childhood. ${ }^{104}$ These rights have been defied by the North Korean state. As a result, the international community must respond and offer tangible efforts to curb the maltreatment of young people in the nation. Advocacy and a demand for information is an important first step, but ultimately, to protect the fundamental rights of these young people, there must be greater involvement in preserving their right to childhood.

Peter Steele is a Graduate student in International Development Studies at Dalhousie University. In general, Peter's research and academic interests focus on the intersections of global health and conflict, as well as the international standing of children in vulnerable situations. Born and raised in Halifax, Peter studied Neuroscience and Development Studies at the undergraduate level, with an academic focus of instances of PTSD among child soldiers in the Democratic Republic of the Congo. Following his undergraduate degree, Peter returned to Dalhousie to focus on the systems of mental health care available for war-affected youth in Northern Uganda.

101 OHCHR, Commission of Inquiry - Afternoon, Aug. 20, 2013, pg. 46.

102 OHCHR, Commission of Inquiry - Morning, Aug. 21, 2013, pg. 10.

103 OHCHR, Commission of Inquiry - Morning, Aug. 22, 2013, pg. 52.

104 General Assembly Resolution, CRC, pg. 1-12. 